International Journal of Engineering \& Technology, $7(4.36)(2018) 524-529$
International Journal of Engineering \& Technology
SPC
Website: www.sciencepubco.com/index.php/IJET
Research paper

\title{
Operational Risk Management in A Commercial Bank
}

\author{
I.I.Vasiliev ${ }^{1}$, P.A. Smelov ${ }^{2}$, N.V. Klimovskih ${ }^{3}$, M.G. Shevashkevich ${ }^{4}$, E.N. Donskaya ${ }^{5}$ \\ ${ }^{1}$ Candidate of Economic Sciences, Associate Professor, Financial University under the Government of the Russian Federation \\ ${ }^{2}$ Candidate of Economic Sciences, Associate Professor, Director of the Situation Center, Plekhanov Russian University of Econom- \\ ics, Moscow, Russia \\ ${ }^{3}$ Candidate of Economic Sciences, Associate Professor, Kuban State University \\ ${ }^{4}$ Candidate of Technical Sciences, Doctor of Economics, Professor, Director of Balakovo Institute of Engineering and Technology of \\ the National Research Nuclear University MEPhI (Moscow Engineering Physics Institute) \\ ${ }^{5}$ Candidate of Economic Sciences, Associate Professor, Head of the Department «Economy, the Organization and Management at \\ the Enterprises» Balakovo Institute of Engineering and Technology of the National Research Nuclear University MEPhI (Moscow \\ Engineering Physics Institute)
}

\begin{abstract}
The existing financial and economic situation in the world and in Russia impacts the activities of all sectors of the economy, including posing challenges for banks. In the conditions of prolonged instability, the banking community has to pay great attention to the risks taken and to manage them. Among all the risks that the bank is exposed to, operational risks represent a separate group due to its specifics, a lack of a systematic approach to analysis and a lack of identification criteria requiring more detailed study. The operational risk is unique in that, although it affects virtually all areas of the credit institution, it is difficult to establish and separate it from other bank risks. It should be noted that every year there appear all new types of operational risk that have a strong impact on the activities of the credit institution due to the development of information and computer systems, the complication of the instruments of the stock market and the improvement of business methods. Therefore, regulators of all countries try to constantly improve the regulatory framework related to the management of the operational risk of a commercial bank, based on the recommendations given by the Basel Committee on Banking Supervision.

The article is aimed at developing an effective system for managing the operational risk of a commercial bank.

The empirical level research methods used in this article are a description of what operational risk is, its types, tools and methods of assessment; comparison of operational risk management systems in the studied banks; generalization, analysis and synthesis of the information received; the hypothetical-deductive method is used at the theoretical level.

Modernization and improvement of the operational risk management system helps stabilize the bank, increase stability and increase profitability, reduce the provision of capital for operational risk, and increase the attractiveness of banking services for consumers, thus benefiting a credit institution among competitors. In today's financial environment, the effective operational risk management is inherent in the long-term development strategy.
\end{abstract}

Keywords: risk, operational risk, operational risk management system, Basel Committee, assessment method.

\section{Introduction}

The relevance of the article is predetermined by the fact that the modern world does not stand still, there are not only positive, but also negative changes. The global crisis, the imposition of sanctions, political tension are the factors that leave a trace The existing financial and economic situation impacts the activities of all sectors of the economy, including posing challenges for banks. In the conditions of prolonged instability, the banking community has to pay great attention to the risks taken and to manage them. Among all the risks that the bank is exposed to, operational risks represent a separate group due to its specifics, a lack of a systematic approach to analysis and a lack of identification criteria requiring more detailed study.

Regulators of all countries try to constantly improve the regulatory framework related to the management of the operational risk of a bank, based on the recommendations given by the Basel Committee on Banking Supervision. The recommendations of the Basel Committee are related, among other things, to the provision of capital to cover operational risk.

There are unsolved issues that relate to the methods of assessing and managing the operational risk of the bank. It is very important to take into account the size of the credit institution in the process of managing this type of risk, which is not being done now. Top-10 banks have more resources for assessing and managing the operational risk than top 50 banks Top 50 banks often cannot afford to take advantage of advanced approaches because of the high cost of the software or do not have a sufficient base for operational risk events. All these factors make it necessary for commercial banks to manage the operational risk, and the topic of the article is relevant.

The issues studied in the article have been considered by outstanding Russian and foreign economic experts. Among Russian scientists, O. V. Boronikhin, N. I. Valentseva, Ye. L. Zolotarev, A. V. Kulikova, O. I. Lavrushina should be noted Foreign scientists studying operational risk management include D. Allen, H. Cading and K. Frost. 
In Russia, the issues related to the management of operational risk in a commercial bank are covered in the regulations of the Central Bank. In foreign experience, the recommendations on operational risk management are provided by the Basel Committee on Banking Supervision. In addition, the rating agencies, like Standart \& Poors and Fitch Ratings, and the "Big Four" audit companies are actively engaged in this matter.

\section{Goals and Objectives}

The goal of the article is to develop an effective system for managing the operational risk of a commercial bank.

To achieve the goal of this article, the following tasks have been set: to determine the economic and legal aspects of managing the operational risk in the bank; to study the methodological bases of operational risk management in the bank used abroad and in Russia, as well as in two banks under consideration; to establish possible directions for the development of operational risk management in the studied banks.

The article poses practical importance for the studied banks and will be useful for all those who are interested in the issues related to the management of the operational risk in a commercial bank.

\section{Methods and Materials}

In carrying out their activities, banks are constantly faced with various types of risks, to which the changing environment of the functioning of banks are exposed.

It is known that the risk is inherent in the activities of any bank and is briefly interpreted as the possibility of loss or damage, as well as the degree of danger [3].

Among all types of banking risks, the relatively new operational risk has recently begun to play a big part. Despite the low level of knowledge, this type of risk has already brought serious losses to the banking sector around the world. According to the research by ORX Association, a Swiss non-profit industry association dedicated to improving the measurement and management of operational risk in the global financial services industry, for October 2014, global losses totaled 7.8 billion US dollars (see Figure 1). It should be noted that the indicators of losses from the operational risk and, consequently, the frequency of their occurrence has tended to decrease since July 2015 So, in September 2015, the total losses for all countries amounted to just under 1 billion US dollars. This decline is caused by the "dead" summer season in the banking sector, and it should not be taken as a long-term trend, since losses from this type of risk will grow in the coming months [4]. The study involved 75 credit institutions from Africa, Asia, Eastern and Western Europe, Latin and North America.

In 2015, the global average loss from 47,000 recorded events of the operational risk amounted to 608,000 US dollars. The distribution of losses from operational risk events in the banking sector is shown in Figure 1.

As follows from Figure 1, during the whole period, the most frequent operating losses occurred within the "corridor" of 20-50 thousand dollars. In the remaining cash intervals in 2015, yearon-year, there was an increase in the frequency of the occurrence of operational risk events.

In 2015, the global average loss from 47,000 recorded events of the operational risk amounted to 608,000 US dollars.

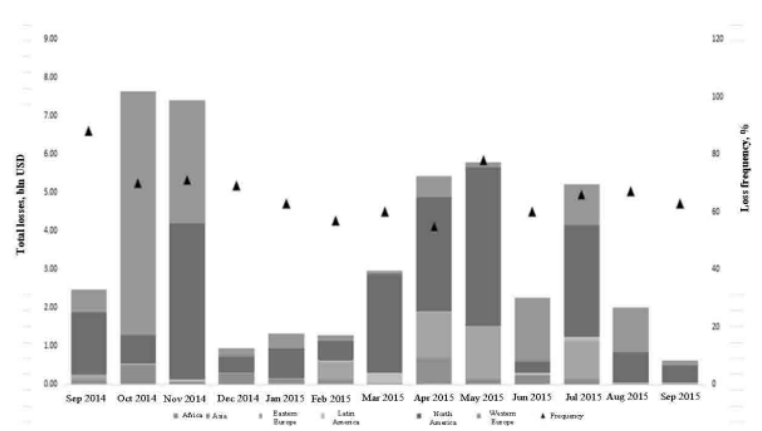

Fig.1: Total losses of the banking sector from the occurrence of the operational risk and the frequency of losses for September 2014 till September 2015 according to the ORX association. Compiled by the author on the basis of ORX association data: ORX News Monthly Top 5 Stories - September 2015 [electronic resource]. Access mode: https://www.orx.org/Pages/LatestNews.aspx. (date of inquiry: $1 / 10 / 2018$ )

The distribution of losses from operational risk events in the banking sector is shown in Figure 1.

However, the results of another study conducted held by the above-mentioned ORX association, which were announced at the forum on the development of common standards of operational risk, innovative research and collective learning, indicate a fairly large amount of operational losses around the world (see Table 1).

Thus, the operational risk is a specific type of risk posing significant losses to the banking sector, an information base and a systematic approach to analysis of which is not fully developed, which makes its study more relevant.

In Russia, the detailed interpretation of the operational risk is presented by the Regulator.

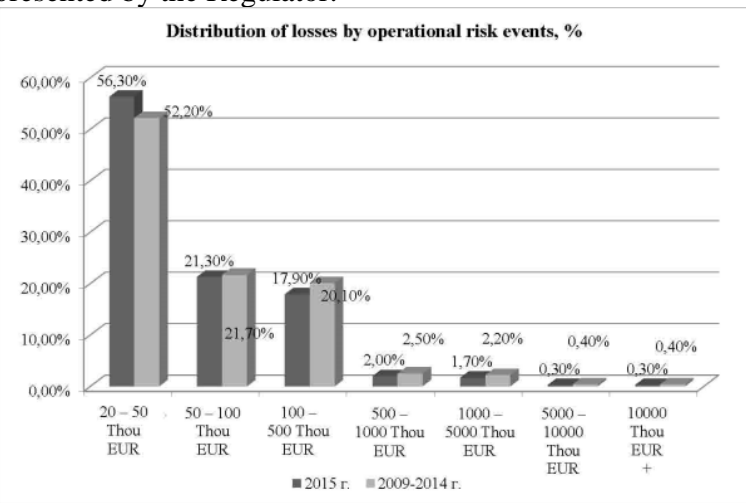

Fig. 1: Distribution of losses by operational risk events, \%. Compiled by the author on the basis of ORX association data: 2015 ORX Report on Banking Operational Risk Loss Data [electronic resource]. Access mode: http://www.orx.org/pages/ORXData.aspx. (date of inquiry: 1/10/2018)

Table 1: Global losses from operational risk by region in 2009-2015, million EUR.

\begin{tabular}{|l|l|l|l|l|}
\hline Region & $\begin{array}{l}\text { Losses in } \\
2009-2014, \\
\text { million USD }\end{array}$ & Share, \% & $\begin{array}{l}\text { Losses in } \\
2015, \\
\text { million } \\
\text { USD }\end{array}$ & Share, \% \\
\hline Africa & 0.87 & $0.50 \%$ & 0.35 & $0.50 \%$ \\
\hline Asia and Oceania & 6.94 & $4.30 \%$ & 1.03 & $3.60 \%$ \\
\hline Eastern Europe & 4.39 & $2.70 \%$ & 0.89 & $3.10 \%$ \\
\hline Latin America & 4.78 & $3.00 \%$ & 1.20 & $4.20 \%$ \\
\hline North America & 80.41 & $49.90 \%$ & 9.67 & $33.80 \%$ \\
\hline Western Europe & 63.88 & $39.60 \%$ & 15.64 & $54.70 \%$ \\
\hline
\end{tabular}

Compiled by the author on the basis of ORX association data: ORX News Monthly Top 5 Stories - January 2016 [electronic resource]. Access mode: https://www.orx.org/Pages/LatestNews.aspx. (date of inquiry: 1/10/2018).

The operational risk is unique in that, although it affects virtually all areas of the credit institution, it is difficult to establish and separate it from other bank risks. $\mathrm{n}$ addition, this type of risk is 
of a dual nature: on the one hand, it contains losses for the bank and, on the other hand, it carries a possible profit.

The operational risk management system depends on the nature, complexity and size of the risk, and it must also correspond to a single process of risk management in the bank.
Let's consider the operational risk management system, the elements of which are presented in Table 1.

Table 2: Elements of the operational risk management system [5].

\begin{tabular}{|c|c|}
\hline Item & Essence \\
\hline Risk Identification & $\begin{array}{l}\text { Identification of operational risk for all systems and equipment, business lines and products. } \\
\text { Structuring information about potential losses and applying preventive measures to high-risk events. } \\
\text { Use of internal tools of communication for transmission of data on operational risks. } \\
\text { Assessment of the potential of new risk products. }\end{array}$ \\
\hline $\begin{array}{l}\text { Continuous monitor- } \\
\text { ing }\end{array}$ & $\begin{array}{l}\text { Introduction of automation elements in the management process. Constant verification of business lines for exposure to opera- } \\
\text { tional risk. } \\
\text { Development of internal reporting on operational risk. }\end{array}$ \\
\hline Unified management & $\begin{array}{l}\text { Operational risk management. } \\
\text { Creation of a database on operational risk events. } \\
\text { Creation of a system of unified information flows, which will help the board of directors to effectively and operatively manage } \\
\text { operational risk. }\end{array}$ \\
\hline
\end{tabular}

All new products of the bank should be checked for exposure to the operational risk. This is extremely important, especially when it comes to transactions of mergers and acquisitions. These transactions often undermine the bank's ability to assess the operational risks [6].

The bank's activities in managing the operational risk in Russia are based on both Russian and international legislation.

In Russia, the issues related to the management of operational risk in a commercial bank are covered in the regulations of the Central Bank.

The complexity of using advanced approaches in Russian practice lies in the absence of a base for operational risk events as well as the shortage of human resources, the high cost of technology and the inadequate development of the corporate culture of operational risk management in small banks. Moreover, the management system for this type of risk must comply with international and Russian requirements (Basel III and the Central Bank).

The Based Indicative Approach (BIA) is an approach that is mandatory for all credit institutions in Russia, in which the operational risk included in the capital adequacy ratio of $100 \%$ is calculated by the following formula:

$\mathrm{OP}=0,15 * \frac{\sum_{i=1}^{n} \mathrm{~A}_{i}}{n}$,

where OP is the amount of operational risk;

$\mathrm{n}$ is the number of years preceding the reporting date (usually 3 years);

Д is the income of the bank, equal to the amount of net interest and non-interest income.

In addition to the basic indicative approach, large Russian banks apply a standardized approach (TSA). The activity of a credit institution under this approach is divided into 7 business lines: corporate finance, sales, retail business, commercial business, settlements and payments, brokerage operations and asset man- agement. The gross revenue for each of the business lines is determined by the cumulative total under the following formula:

\section{ВД $=$ (ЧПД + ЧНПД) - РВП - OP - ПР/ПД}

where ВД is the gross business line income,

ЧПД is the interest income (net),

ЧНПД is the non-interest income (net),

РВП is the cost of reserves for possible losses,

$\mathrm{OP}$ is the operating costs,

ПР is other costs,

ПД is the other income.

There is an alternative standardized approach (ASA). It differs from the standardized ratio $\mathrm{m}=3.5 \%$, which weighs the portfolios of loan debt of legal entities and individuals, used as the main indicator for the retail and corporate banking business, which makes it possible to be more objective in the calculations and focus more on these areas of banking activities.

The formula for retail business is:

\section{$\mathrm{KPБ}=\beta \_\mathrm{PB} * m * \mathrm{KA} \_\mathrm{PB}$,}

where КРБ is the capital reserved for the retail business,

$\beta$ РБ is a beta for retail business,

$\mathrm{m}$ is the coefficient established by the Basel Committee on Banking Supervision,

КА_РБ is the total amount of outstanding loans and loans for retail including reserves and not weighing by risk (average for 3 years).

Substituting the corresponding values for corporate banking clients, we obtain capital requirements for this line of banking activity.

So, international approaches to managing the operational risk can only be applied by large Russian banks in view of the com- 
plexity and these methods are costly. But even they are not always expected to use advanced approaches,sometimes there would be enough to use a simple, but understandable, and most importantly working model.

\section{Results and Discussions}

Let's consider the methods used in the studied banks, which are included in the top 50 by assets.

The first bank on which this research is based is Public JointStock Company Transcapitalbank (PJSC BANK TCB).

The concept and classification of the operational risk according to the risk management declaration presented on the bank's official website comply with the concept and classification of the Central Bank of the Russian Federation.

Within the existing system of operational risk management, the bank adheres to the following principles: reasonable conservatism, i.e. regardless of the chosen business development strategy, the operational risk should not exceed the maximum allowable risk, regardless of the size of the potential benefit; awareness of risk; decisions on any operation are made only after a comprehensive analysis of risks, including. Operational risk, arising as a result of such operation.

According to the bank's documents, the level of operational risk equal to $20 \%$ is considered normal. All that is lower is a "low" risk and all that is higher is a "high" risk and requires minimization, according to the bank's documents, reputational and legal risks are included in the operational risk.

PJSC BANK TCB includes operational risk as one of the types of non-financial risks in calculation of the total risk appetite indicator and the subsequent formation of a risk map. The cumulative level of risk appetite, each type of risk / valuation of capital / assessment of profitability is estimated on a scale from 1 up to 3. Depending on the assigned score, the risk category is placed in one of the three risk areas (see Table 3):

Table 3: Bank risk areas [7].

\begin{tabular}{|c|c|c|c|}
\hline No. & Risk area & Range & Exposure level \\
\hline 1 & Green & $1-1.5$ scores & Satisfactory \\
\hline 2 & Yellow & $1.6-2.5$ scores & Increased \\
\hline 3 & Red & Over 2.5 scores & High \\
\hline
\end{tabular}

Green area: the level of risk is satisfactory.

Yellow area: the level of risk is increased.

Green area: the level of risk is satisfactory.

Red area: the level of risk is high.

$$
\mathrm{CP}=\sum\left(O_{i} * B_{i} * K_{i}\right),
$$

where Oi is the score of the capital / estimation of profitability / strategic risk / liquidity risk / credit risk / market risk / nonfinancial risks;
$\mathrm{Bi}$ is the weight of the Oi estimate, for non-financial risks, equal to 0.1 ;

$\mathrm{Ki}$ is the increasing coefficient, assigned depending on the risk area, where the risk-appetite index is located; it takes the following values: green area - 1 point; yellow area -1.5 points; red area -2 points.

Further, a risk map is drawn up and an appropriate assessment is carried out.

In general, it can be concluded that the Bank's analytics with the use of accumulated data helps manage and minimize risks more effectively; however, it needs to be improved.

Public Joint Stock Company "Vozrozhdenie Bank" is another bank under study. The quality of risk management of the bank, including such type as operational risk plays an important role in high positions held by this bank. In recent years, the internal regulatory framework regarding the collection and processing of information on risk events has been updated, and the system for monitoring compliance with maximum exposure targets has been modernized and tightened.

In order to reduce the bank's liability for operational risk associated with withdrawing money from compromised bank cards, the bank issues chip cards, which according to the rules transfer responsibility to the cardholder. ATMs are equipped with alarm and CCTV cameras, which reduces one of the main operational risks, i.e. cash theft [8].

The classification of operational risks used by this bank is consistent with the approach of the Central Bank of the Russian Federation. As an expression of this type of risk, the bank understands: decrease in the value of assets; preliminary disposal of assets; cash payments due to litigation; cash payments to counterparties and customers for compensation in extrajudicial matters; other losses.

The bank has a system for controlling and monitoring risks, as well as an information system and a system for setting limits and making decisions. In order to minimize the operational risk, a number of procedures is carried out, such as: audit of user actions; double entry of data by bank employees to verify the accuracy and correctness of information; automation of data entry; protection against unauthorized use of data; control over the execution of documents; connection of automatic verification procedures and setting for error diagnosis.

The studied banks (PJSC "Transcapitalbank" and PJSC Bank Vozrozhdenie) follow the world trends. While assessing risk with simple methods, they also apply qualitative assessment of operational risk along with the quantitative assessment. This is expressed in the construction of a risk map, assigning a rating to risk events on the basis of judgments of experts and setting limits. However, the methods of managing this type of risk in these banks are imperfect and require improvement.

In order to better analyze the studied banks, we will examine their systems in more detail.

Operational risk management bodies in PJSC BANK TCB are represented in Figure 4 


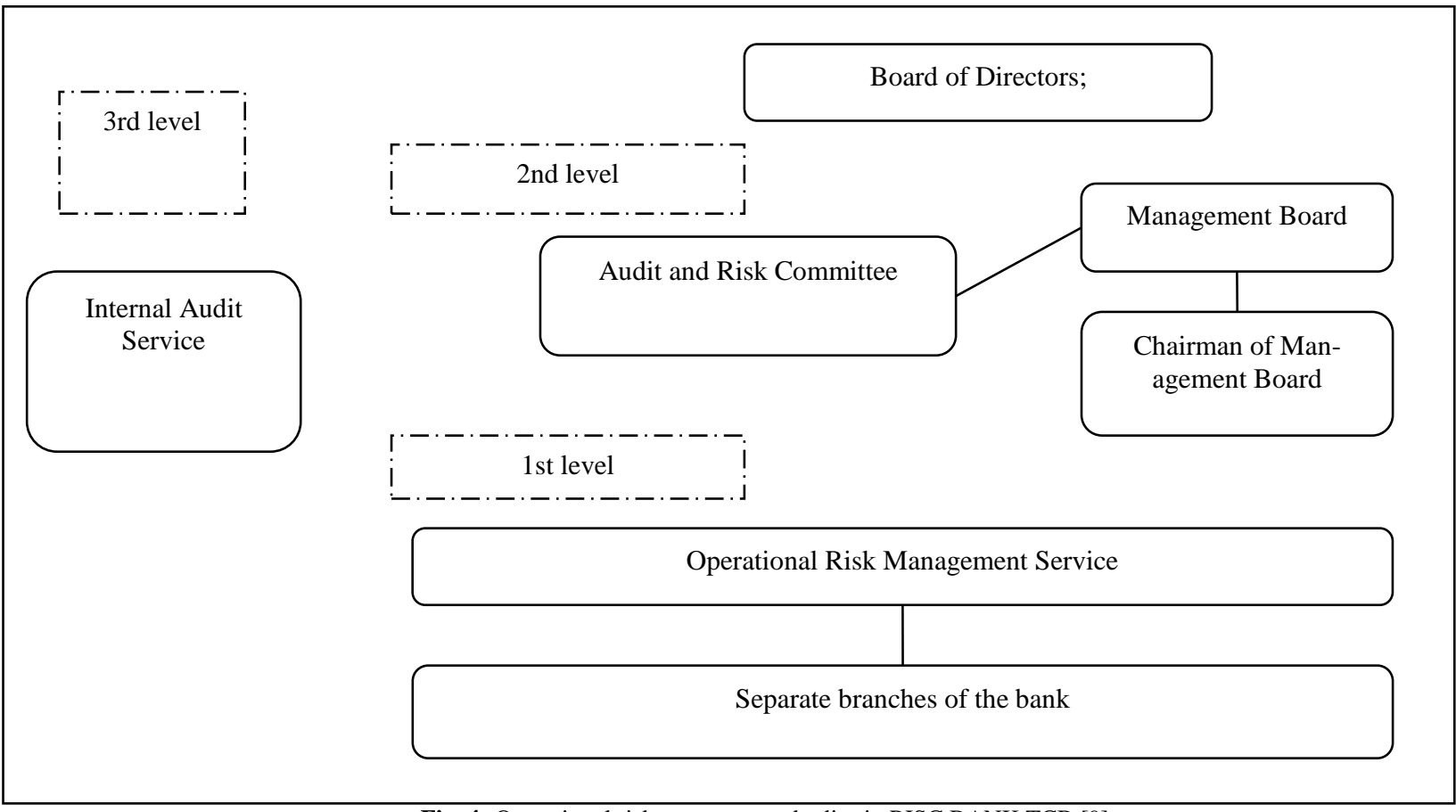

Fig. 4: Operational risk management bodies in PJSC BANK TCB [9].

Operational risk management bodies in PJSC Bank Vozrozhdenie are represented in Figure 1.5
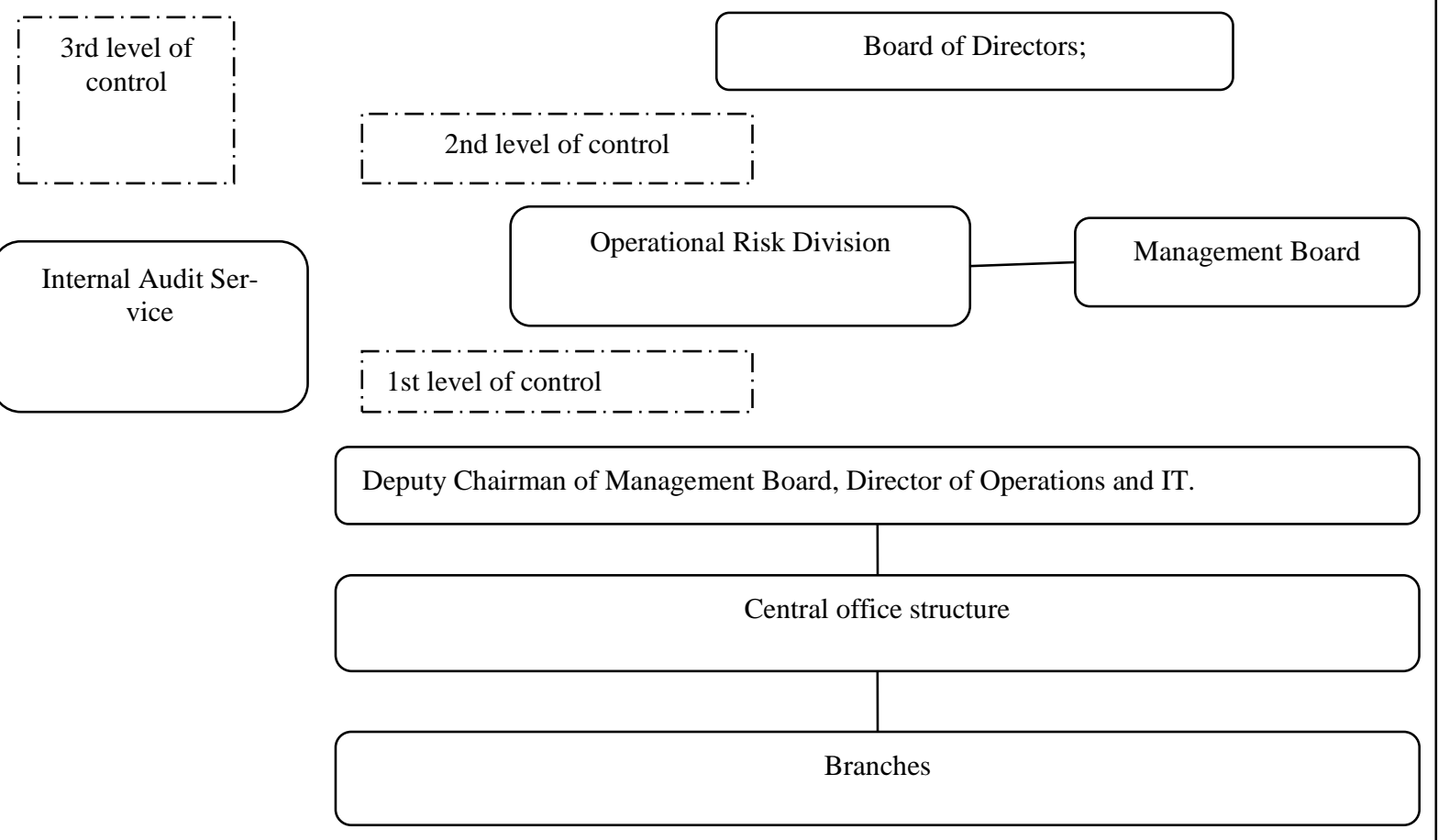

Fig. 5: Operational risk management bodies in PJSC Bank Vozrozhdenie [10].

It can be concluded that both banks have all the criteria for assessing the operational risk. Despite this, the studied banks still need to improve existing systems.

\section{Conclusions}

Credit institutions around the world are becoming increasingly aware of the importance of operational risk management in every day operations. The likelihood of operational risk events is also growing due to the increasing integration of international financial institutions and the expansion of the range of banking services. The operational risk management capable of minimizing this risk and maintaining it at the required level is relevant. Ignoring the processes of managing operational risk impacts the financial stability of the credit institution, leading to a lack of benefits or even loss of business reputation.

The operational risk management is impossible without taking into account its characteristics, which include classification, effects, areas. Factors, objects and subjects of risk. The complexity of identification is a specific feature. This risk is ambiguous, that is, in addition to the inherent losses, it touches profit as well. All this must be taken into account in the process of risk management.

Operational risk is paid attention both in international and in Russian legislation. The Basel Committee on Banking Supervi- 
sion and the Central Bank of Russia have issued a number of regulatory documents in this area, the latest of which are the "Principles for the Sound Management of Operational Risk" BCBN and the Directive of the Bank of Russia.

To date, there are both international and Russian approaches to managing the operational risk. The first group includes the socalled advanced methods recommended by the Basel Committee on Banking Supervision and requiring that the credit institution has an extensive base on events of the operational risk and expensive software for making calculations. This includes the Internal Measurement Approach (IMA), the Loss distribution approach (LDA), a method related to probability distribution, and the Scorecard approach (SCA) or a method based on evaluation cards. For many small credit institutions, the use of advanced methods is impossible because of the high monetary costs and the lack of accumulated data. For them, there are simple assessment methods that are also used abroad and popular in Russia: the basic indicative approach (BIA), which is mandatory for all credit institutions in the country, the standardized approach (TSA) and an alternative standardized approach (ASA).

All of the above methods are quantitative, but there also exist qualitative approaches. Each bank chooses that method of assessing the operational risk, which it considers most acceptable by the cost/result ratio and satisfies its strategy.

The application of only one method of risk assessment is not enough. The credit institution must have a comprehensive management system. When constructing the operational risk management system, the credit institution must comply with the principle of business continuity, which is of great importance to its counterparties.

Using the example of two banks under study, the research in this paper has examined operational risk management systems.

It has been found that the management of this type of risk in both banks is built similarly. Each of them determines for itself what the operational risk is, distinguishes classification characteristics, as well as goals, objectives and management principles. The article proposes an "optimal" model based on foreign and Russian practices. The created management model has gradually begun to be introduced in banks and has already managed to bring some results. So, since the 1st quarter of 2015 the risk level calculated by the basic approach has been decreased by $13 \%$ at PJSC BANK TCB and by $4 \%$ at PJSC Bank Vozrozhdenie. Actual operating losses has been decreased by $23 \%$ and by $15 \%$, respectively. It can be concluded that the proposed model effectively works and is needed by the said banks.

PJSC "Transcapitalbank" and PJSC Bank Vozrozhdenie will be able not only to minimize its exposure to the operational risk with the help of an improved management system, but also to obtain more profit by reducing costs, and, therefore, to carry out activities more efficiently.

\section{References}

[1] Gersh, M.B. (2014). Corporate culture / Gersh M.V. // ATP "Consultant Plus". - Human Resources Department of a Commercial Organization. , No. 3. - pp. 24.

[2] Savchuk, K.V. (2013). Mathematical Modeling of Operational Risk in a Commercial Bank: Thesis of Savchuk K.V., Candidate of Economic Sciences: 08.00.10 / Savchuk Konstantin Vladimirovich. Moscow, pp. 151.

[3] On the Organization of the Operational Risk Management in Credit Institutions: Letter of International Convergence of Capital Measurement and Capital Standards: New Approaches: Basel Committee on Banking Supervision, June 2004 [electronic resource] // The official website of the Bank of Russia. - Access mode: http://www.cbr.ru/today/ms/bn/Basel.pdf. (date of inquiry: $1 / 10 / 2018$

[4] Sound Practices for Management and Supervision of Operational Risk // Basel Committee on Ba Viatkin V.N., Gamza V.A., Maevskii F.V. Risk Management. Textbook. M.: Publishing House URAIT, 2015. - P. 204.nking Supervision. - February 2003. Russian Gazette No. 76-T dated May 24, 2005
[5] Naturina, M., Gromenko, O. (2014). Operational Risk Management: Analysis of Data on Operational Losses, BDC-Press / Operational Management and Strategic Management in a Commercial Bank. -No. 6.

[6] The Risk Management Declaration in PJSC BANK TCB dated December 31, 2015.

[7] Official website of PJSC "Bank Vozrozhdenie". Access mode: http://www.vbank.ru/investors/risk_management/operational/ (date of inquiry - January 10,2018), Regulations on the Organization of Operational Risk Management at PJSC "Bank Vozrozhdenie" of December 31, 2015, URL: http://www.vbank.ru/investors/risk_management/operational/ (date of inquiry - January 10, 2018)

[8] Official website of PJSC BANK TCB URL: http://www.tkbbank.ru/bank/disclosure/risk_management/ (date of inquiry - January 10, 2018)

[9] International Convergence of Capital Measurement and Capital Standards // Basel Committee on Banking Supervision. - June 2006.

[10] Operational risk - Revisions to the simpler approaches - consultative document // Basel Committee on Banking Supervision. - October 2014.

[11] Operational Risk - Supervisory Guidelines for the Advanced Measurement Approaches // Basel Committee on Banking Supervision. - June 2011.

[12] Principles for the Sound Management of Operational Risk - final document // Basel Committee on Banking Supervision. - June 2011

[13] FSI Survey. Basel II, 2,5 and III Implementation // Financial stability Institute. - July 2015.

[14] Risk in Review: Reevaluating how your company addresses risk // PwC. - March 2014. 